\title{
Sub-Chronic Administration of Vincristine Sulfate Induces Renal Damage and Apoptosis in Rats via Induction of Oxidative Stress and Activation of Raf1-MEK1/2-Erk1/2 Signal Transduction
}

\author{
La Administración Subcrónica de Sulfato de Vincristina Induce Daño Renal y Apoptosis en Ratas \\ por Inducción de Estrés Oxidativo y Activación de la Transducción de Señales Raf1-MEK1/2-Erk1/2
}

Ali A. Shati

SHATI, A. A. Sub-chronic administration of vincristine sulfate induces renal damage and apoptosis in rats via induction of oxidative stress and activation of Raf1-MEK1/2- Erk1/2 signal transduction. Int. J. Morphol., 37(1):273-283, 2019.

SUMMARY: In spite of being one of the most powerful anti-cancer drug, the nephrotoxicity of Vincristine (VCR) is not well established in either animals or humans. Hence, this study evaluates the nephrotoxic effect of VCR in rats after sub-chronic long-term administration. Rats were divided into 2 groups ( $\mathrm{n}=10 /$ group) of either control and VCR treated rats $(50 \mathrm{mg} / \mathrm{kg}$ ). Treatments were carried out for 30 consecutive days, after which a series of biochemical and molecular experiments related to kidney function were evaluated. VCR administration significantly decreased the survival rate $(69.8 \%)$ and impaired renal function as evidenced by lowered creatinine $(\mathrm{Cr})$ clearance $(\mathrm{Ccr})$, high serum levels of urea and $\mathrm{Cr}$, increased urinary protein levels and resulted in sever cortex pathological alterations, including glomerulus congestion and damage as well as vascular degenerations up to necrosis of both proximal and distal convoluted tubules. Mechanistically, VCR lowered renal antioxidant potential and ATP levels, enhanced lipid peroxidation and induced inflammation. In addition, VCR induced activation of Raf-1-MEK1/2-ERK1/2 signaling pathway leading to downregulation of Bcl2 and upregulation of P53, Bax, and cleaved caspase-3. In conclusion, these findings show a nephrotoxic effect of VCR sulfate in rats after sub-chronic administration and such effect was mediated by activation of ERK1/2 induced apoptosis.

KEY WORDS: Vincristine; Nephrotoxicity; Oxidative stress; Apoptosis; Rats.

\section{INTRODUCTION}

Acute kidney injury (AKI) and electrolyte disturbances are the most common forms of renal complications that may occur in a hospitalized cancer patient (Lameire et al., 2010; Salahudeen \& Bonventre, 2013). Epidemiologic reports on the impact of chemotherapy on renal function of the oncologic population are scarce and alarming (Salahudeen \& Bonventre). Renal complications associated with chemotherapeutic drugs include glomerular disease (Glezerman et al., 2009) and tubulointerstitial damage (Suarez et al., 1991; Yao et al., 2007). This is not surprising as kidneys are one of the most highly vulnerable organs in the body to drug-induced toxicity due to the high blood supply they receive ( $25 \%$ of cardiac output), their significant capacity to uptake drugs via endocytosis or transporter proteins and their crucial role in the metabolism, excretion and elimination of toxic agents and their metabolites (Salahudeen \& Bonventre; Lameire et al.).
Vincristine (VCR) is a drug of plants origin with antineoplastic properties and is widely used for the treatment of numerous malignancies (Blasko \& Cordel, 1990; Jordan, 2002). High capacity of binding of normal tissue to VCR results in high accumulation rate and limits its tumor tissue exposure leading to adverse cytotoxicity to non-neoplastic tissues (Martins et al., 2011; Kumar, 2016; Vashistha et al., 2017). Indeed, VCR accumulates at high rates in most organs and tissues with the exception of the brain, eye, and fat (Said \& Tsimberidou, 2014; Khalil et al., 2016; Kumar). In this regard, soft-tissue necrosis and ulceration (if accidentally extravagated) (Choy et al., 1979; Bellone et al., 1981), respiratory distress, neurotoxicity and neuropathy (Egbelakin et al., 2011; Muthuraman \& Singh, 2011), gastrointestinal toxicities (Cave et al., 2007), hepatotoxicity (Roger 2006; Upmanyu et al., 2011), and infertility (Arnon et al., 2001) have been described in patients who received short-term administration of VCR.

Biology Department, College of Science, King Khalid University, Abha, Saudi Arabia. 
VCR-induced tissue cytotoxicity is mediated mainly by induction of apoptosis (da Silva et al., 1996; Mollinedo \& Gajate, 2003) and to a lesser extent by induction of necrosis (Kesik et al., 2010). CVR-induced apoptosis was found to be as a result of disruption of microtubules, arrest of cell cycle division during the metaphase, inhibition of synthesis of proteins and nucleic acids, and induction of oxidative stress and inflammation (Jordan; Mollinedo \& Gajate; Muthuraman \& Singh; Canta et al., 2015; Vashistha et al.). However, VCR-induced necrosis is mainly mediated by interfering with vascular blood flow (Kesik et al.).

In the renal tissue, nephrotoxic drugs inappropriately activate some proteins, including those important elements of signaling cascades such members of mitogen-activated protein kinase (MAPK) family (Cassidy et al., 2012). MAPK includes three family members: extracellular-signal-regulated kinase (ERK), cJun N-terminal kinase (JNK) and p38 MAPK (Rose et al., 2010). ERK $1 / 2$ activation generally promotes cell survival; but under certain conditions such as sustained activation, ERK1/2 can have pro-apoptotic functions ( $\mathrm{Lu} \& \mathrm{Xu}, 2006$ ). Indeed, ERK1/2 activation in the neural tissue induced neurodegeneration whereas its inhibition induced protection (Stanciu et al., 2000; Kulich \& Chu, 2001; Cheung \& Slack, 2004). Moreover, activation of ERK1/2 mediates the DNA damaging effects of etoposide, adriamycin, platinum compounds, ionizing irradiation, and ultraviolet (UV) irradiation (Tang et al., 2002; Billecke et al., 2006; Lu \& Xu). In addition, the nephrotoxicity of some chemotherapeutic agents such as cisplatin is mediated mainly by the sustained activation of ERK1/2 (Wang et al., 2000; Nowak, 2002; Arany et al., 2004; Potocnjak \& Domitrovic, 2016). Furthermore, ERK1/2 activationinduced apoptosis has been reported with several other nephrotoxins agents (Kohda et al., 2003).

About 8 to $15 \%$ of VCR is excreted in the urine as unchanged VCR (Bedikian et al., 2006; Dennison et al., 2007; Hamdy et al. 2012; Said \& Tsimberidou; Khalil et $a l$.), indicating susceptibility of the kidney to cytotoxicity of VCR. In support, a sign of renal dysfunction such as hyperuricemia has been reported in patients who received short-term VCR treatment (Hummel et al., 2003). However, the nephrotoxic effect of VCR is poorly described in the literature. This could be due to dose limitation or due to the limited studies that have investigated the nephrotoxic effect of VCR after long-term or chronic administration. Hence, this study was designed to investigate the molecular effect of long-term repetitive administration of VCR sulfate on renal function, structure, and apoptosis in respect to its effect on oxidative stress and ERK1/2 activation.

\section{MATERIAL AND METHOD}

Animals: Adult male Wistar rats (180-200 g) were supplied from the animal facility at the College of Science at King Khalid University (KKU), Abha, Kingdom of Saudi Arabia (KSA). Animals were always housed in the light temperaturecontrolled room $\left(23 \pm 1^{\circ} \mathrm{C}, 12 / 12 \mathrm{~h}\right.$ light/dark cycle $)$ and had free access to water and chow. All experimental procedures carried out in this study were approved by the animal research ethics committee of KKU which are in accordance with the regulations of laboratory animal care and use published by the US National Institutes of Health (NIH publication No. 85-23, revised 1996).

Experimental design: VCR sulfate (Cat NO. V0400000, Sigma-Aldrich, UK) was freshly and daily prepared by dissolving in normal saline to a final concentration of 200 $\mu \mathrm{g} / \mathrm{ml}$. Rats were divided into two main groups ( $\mathrm{n}=20 / \mathrm{group}$ ) of 1) a control group: administered with normal saline, and 2) a VCR-intoxicated group: administered with VCR sulfate $(50 \mathrm{mg} / \mathrm{kg})$. All treatments were administered at a single dose/day (i.p.) for consecutive 30 days. The similar repetitive dose of VCR sulfate was chosen in this study based on previous findings that showed such dose for 10 days in rats is able to induce pain and peripheral neurotoxicity (Kaur $e t$ al., 2010; Vashistha et al.).

Blood, urine and tissue collection: During the experimental procedure, 7 rats were died in the VCR treated group during the experimental procedure. Therefore, the experimental analysis was performed using 10 rats per group. Twelve hours after the last treatments, 10 rats from each group were individually housed in separate metabolic cages (Cat No. 52-6715, Harvard Apparatus, MA, USA) supplied with water and chow. These cages allow the separation of feces and urine in tubes outside the cage and maintain them uncontaminated with water and food. A $24 \mathrm{~h}$ urines samples were collected from each rat. Then, all animals were anesthetized with sodium pentobarbital $(60-70 \mathrm{mg} / \mathrm{kg}$, i.p.) and $2 \mathrm{ml}$ of blood were directly collected from their aortas, centrifuged at $5000 \mathrm{rpm}$ for 10 minutes to collect sera. After that, all animals were killed by cervical dislocation and their kidneys were removed on ice. Both kidneys were cut into small pieces from which some pieces were directly placed in $10 \%$ buffered formalin for histological evaluation and other parts were stored at $-80{ }^{\circ} \mathrm{C}$ for reverse transcriptase polymerase chain reaction (RT-PCR) and renal biochemical evaluation.

Serum parameters and creatinine $(\mathrm{Cr})$ clearance: Serum and urinary levels of sodium, urea, creatinine $(\mathrm{Cr})$ and uric acid and serum levels of blood urea nitrogen (BUN), as well 
as urinary protein levels, were determined using a biochemical analyzer (ADVIA 1200 SIEMENS analyzer). $\mathrm{Cr}$ clearance $(\mathrm{Ccr})$ was calculated using the following equation:

$\mathrm{Ccr}(\mathrm{ml} / \mathrm{min} / \mathrm{kg})=[$ urinary $\mathrm{Cr}(\mathrm{mg} / \mathrm{dl}) \times$ urinary volume $(\mathrm{ml} /$ $\min ) /$ serum $\mathrm{Cr}(\mathrm{mg} / \mathrm{dl})] \times[1000 /$ body weight $(\mathrm{g})] \times[1 /$ $1440(\min )]$.

Biochemical Measurements in renal homogenates: To prepare renal homogenates, renal tissues ( $n=10 /$ group) were homogenized in an appropriate buffer as recommended by the manufacturer's instruction of each kit supplied. Total proteins were extracted from kidney tissues using Bio-Rad protein extraction kit (Catalog \#163-2086) and protein concentrations in the samples were determined using Pierce BCA protein assay kit (Cat. No.23225, Thermo Fisher Scientific). The following parameters were determined in the renal homogenates, total antioxidant capacity (TAC, OxiSelect TAC, Cat No. STA-360, Cell Biolabs, Inc, CA, USA), ATP levels (Cat. No. ab83355, Abcam, UK), carbonyl proteins (Cat. No. KA3741, Abnova, Taiwan), malondialdehyde (MDA, Cat No. ab118970/ Abcam, UK), activities of superoxide dismutase (SOD, Cat. No 706002, Cayman, USA), glutathione peroxidase (Cat. No. ab102530/ Abcam, UK), glutathione reductase (Cat. No. GSHR, ab83461, Abcam, UK) and glutathione-S-transferase (Cat. No. GST, ab65326, Abcam, UK). All procedures were done in duplicate according to the manufacturer's instruction.

RT-PCR: Frozen kidney tissue from 6 rats/group were used for mRNA analysis using RT-PCR. Total RNA was extracted from all frozen kidneys tissue using the RNeasy mini kit (Qiagen Pty. Ltd., Victoria, Australia) and single-stranded cDNA was synthesized for each sample using an Omniscript RT Kit (Qiagen Pty. Ltd., Victoria, Australia). BCL-2, P53, IL-12, IL-4 and b-actin genes were amplified using primers and conditions shown in Table I. In brief, $2 \mu 1$ RT reaction products from each sample in a $20 \mu \mathrm{l}$ reaction containing Taq polymerase $(0.01 \mathrm{U} / \mathrm{ml}), \mathrm{dNTPs}(100 \mathrm{mM}), \mathrm{MgCl} 2(1.5$
$\mathrm{mM})$, and buffer (50 mM Tris- $\mathrm{HCl})$. A control reaction in which reverse transcriptase was omitted was included for every sample of RNA isolated to verify the absence of contamination. PCR products $(10 \mu \mathrm{l})$ were electrophoresed on $1 \%$ agarose gels containing $100 \mathrm{ng} / \mathrm{ml}$ ethidium bromide and photographed with a Polaroid camera under ultraviolet illumination. All images were analyzed using Image J software and data were presented as mean \pm SD of 6 samples/ group.

Western blotting: The protein sample $(60 \mu \mathrm{g})$ were separated by 8-12\% SDS-PAGE gel electrophoresis and transferred manually to nitrocellulose membranes. Membranes were then incubated overnight at $4{ }^{\circ} \mathrm{C}$ with primary antibodies against p44/42 MAPK (ERK1/2, Cat. No. 9101, 42,44 kDa), phospho p-44/42 MAPK (p-Erk1/2 (Thr202/Tyr204), Cat. No 9102, 42,44 kDa), MEK1/2 (Cat. No. 9122, $45 \mathrm{kDa}$ ), p-MEK1/2 (Ser217/221, Cat. No. 9121, $45 \mathrm{kDa}$ ), Bax (Cat. No. 2727, $20 \mathrm{kDa}$ ), Bcl-2 ( Cat. No. 3498, $26 \mathrm{kDa}$ ), P53 (Cat. No 9282, $53 \mathrm{kDa}$ ) and Cleaved caspase-3 (Cat. No. 9662, 17, 19, and $35 \mathrm{kDa}$ ), all of which purchased from Cell Signaling Technology, USA; Raf-1 (Cat. No. E-10: sc-7267, 80 kDa), p-Raf-1 (Cat. No. 6B4: sc81513, 74 kDa), p-Bad (Cat. No. C-10: sc-166932, 22 kDa), and b-Actin (C4, sc-47778), all of which purchased from Santa Cruz Biotechnology, USA. Membranes were stripped up to 4 times in which the detection of phosphorylated protein form was done first and the detection of b-Actin was the last. Antigen-antibody interactions of were detected by chemiluminescence (Pierce ECL reagents, Thermofisher, USA, Piscataway, NJ) and were quantified using C-DiGit blot scanner (LI-COR, USA) with the supplied image studio DiGits software. Protein expressions were presented as relative expressions to the reference gene b-actin. Data were performed in duplicate for 6 rats/group.

Histopathological procedures: Kidney specimens were collected in a small, labeled test tube containing $10 \%$ formalin for light microscopy examination. In the pathology laboratory, the paraffin sections of all samples were prepared

Table I. Primers and conditions used in PCR reactions.

\begin{tabular}{|c|c|c|c|c|}
\hline Target & & Primer sequence (5 to 3 _) & $\mathrm{AT}\left({ }^{\circ} \mathrm{C}\right)$ & Size(bp) \\
\hline \multirow[t]{2}{*}{ p53 } & Sense & 5 - CTACTAAGGTCGTGAGACGCTGCC-3 & 60 & 106 \\
\hline & Antisense & 5 - TCAGCATACAGGTTTCCTTCCACC-3 & & \\
\hline \multirow[t]{2}{*}{$\mathrm{Bcl}-2$} & Sense & 5-ACTTTGCAGAGATGTCCAGT-3 & 55 & 217 \\
\hline & Antisense & 5-CGGTTCAGGTACTCAGCAT-3 & & \\
\hline \multirow[t]{2}{*}{ IL-4 } & Sense & 5-ACCTTGCTGTCACCCTGTTCTGC-3 & 60 & 352 \\
\hline & Antisense & 5-GTTGTCAGCGTGGACTCATTCACG -3 & & \\
\hline \multirow[t]{2}{*}{ IL-12 } & Sense & 5-ATGTTGTAGAGGTGGACTGGCG-3 & 60 & 335 \\
\hline & Antisense & 5-ССТTCTTGTGGAGCAGCAGATG-3 & & \\
\hline \multirow[t]{2}{*}{ B-Actin } & Sense & 5-CGTTGACATCCGTAAAGAC- $3^{c}$ & 55 & 110 \\
\hline & Antisense & 5-TAGGAGCCAGGGCAGTA- ${ }^{\mathrm{d}}$ & & \\
\hline
\end{tabular}


and then were stained with hematoxylin \& eosin (H\&E). Slides were examined under the light microscope and representative sections were photographed using OlympusPM 10 SP automatic micrographic system (Japan).

Statistical Analysis: Statistical analysis was performed using GraphPad Prism statistical software package (version 6). Data were presented as means with standard deviation (mean \pm SD All analysis were done by Student's t-test. Significance was considered at $\mathrm{P}<0.05$.

\section{RESULTS}

Survival rate, final body weight and biochemistry of renal function: While there was no death in the control group, the survival rate of the rats administered VCR was significantly declined to $69.5 \%$ as 7 rats died during the 30 days treatment period (7/20). Four rats died on days 5, 8, 13 and 18, respectively and 3 rats died on day 25 (Fig. 1). In addition, VCR-treated rats had significant decreases in total body weight, serum levels of uric acid, urine $\mathrm{pH}$, urinary levels of uric acid and $\mathrm{Cr}$ urea and $\mathrm{Na}+$ and creatinine clearance (Ccr) with concomitant increases in serum levels of urea, $\mathrm{Cr}$, and BUN as well as urinary levels of protein (Tables II and III) as compared to corresponding control levels. On the other hand and as compared to control, renal levels of total TAC, carbonyl protein content and MDA were significantly increased (Figs. 2A, C and D, respectively) and levels of ATP (Fig. 2B) and activities of hepatic SOD, GPx, GSHR, and GST were significantly decreased (Figs. 2E-H) in the renal homogenates of VCR-treated rats.

Changes in mRNA levels: Renal mRNA levels of Bcl-2, P53, IL-4, IL-12, and b-actin were detected by means of RT-PCR (Fig. 3). All detected bands were within the expected size and constant mRNA levels of b-actin were seen among all groups. When normalized to b-actin, relative

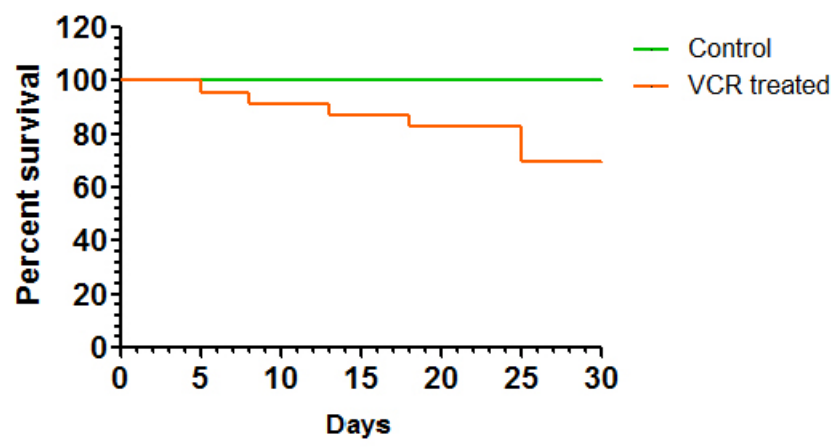

Fig. 1. Survival percentages $(\%)$ of both control and vincristine (VCR)-treated rats.
Table II. Final body weights and serum parameters in the control and VCR treated rats on the last day of the treatment.

\begin{tabular}{lrc}
\hline Parameter & \multicolumn{1}{c}{ Control } & \multicolumn{1}{c}{ VCR } \\
\hline Final body weights $(\mathrm{g})$ & $265 \pm 8.92$ & $238.5 \pm 7.43^{*}$ \\
$\mathrm{Na}(\mathrm{nmol} / \mathrm{L})$ & $152.23 \pm 3.45$ & $149 \pm 4.23$ \\
Urea $(\mathrm{moml} / \mathrm{L})$ & $5.23 \pm 0.87$ & $9.54 \pm 1.23 * * *$ \\
$\mathrm{BUN}(\mathrm{mg} / \mathrm{dL})$ & $16.23 \pm 1.43$ & $22.12 \pm 3.19^{* *}$ \\
Uric acid $(\mu \mathrm{mol} / \mathrm{L})$ & $172.32 \pm 8.72$ & $102.10 \pm 6.47 * *$ \\
Creatinine $(\mathrm{mg} / \mathrm{dl})$ & $0.42 \pm 0.02$ & $0.74 \pm 0.03 * * *$ \\
\hline
\end{tabular}

Values are expressed as Mean \pm SD 10/group. Values were considered significantly different at $* \mathrm{P}<0.05, * * \mathrm{P}<0.01$ and $* * * \mathrm{P}<0.001$ as compared to corresponding control values. VCR: Vincristine. BUN: Blood urea nitrogen.

Table III. Urine parameters in the control and VCR treated rats as collected over $24 \mathrm{~h}$ on the last day of treatment.

\begin{tabular}{lcc}
\hline Parameter & Control & VCR \\
\hline Urine volume $(\mathrm{ml} / 24 \mathrm{~h})$ & $6.32 \pm 0.74$ & $3.21 \pm 0.42^{*}$ \\
$\mathrm{pH}$ & $9.01 \pm 0.003$ & $8.01 \pm 0.006^{*}$ \\
Protein $(\mathrm{mg} / \mathrm{dl})$ & $4.22 \pm 0.34$ & $6.32 \pm 0.54^{*}$ \\
$\mathrm{Na}(\mathrm{nmol} / \mathrm{L})$ & $0.72 \pm 0.06$ & $0.43 \pm 0.02$ \\
Urea $(\mathrm{moml} / \mathrm{L})$ & $6.33 \pm 0.72$ & $3.54 \pm 0.33^{* * *}$ \\
Uric acid $(\mu \mathrm{mol} / \mathrm{L})$ & $13.21 \pm 1.73$ & $7.54 \pm 0.74 * *$ \\
Creatinine $(\mathrm{mg} / \mathrm{L})$ & $48.65 \pm 3.82$ & $22.2 \pm 3.36^{* *}$ \\
Ccr $(\mathrm{ml} / \mathrm{min} / \mathrm{kg})$ & $2.02 \pm 0.23$ & $0.32 \pm 2.4$ \\
\hline
\end{tabular}

Values were considered significantly different at $* \mathrm{P}<0.05, * * \mathrm{P}<0.01$ and $* * * \mathrm{P}<0.001$ as compared to corresponding control values. VCR: Vincristine. Ccr: creatinine clearance.

mRNA levels of IL-4, IL-12, and P53 were significantly increased (Figs. 3A, B and D, respectively) and levels of Bcl2 were significantly decreased (Fig. 3C) in the kidneys of VCR-treated rats as compared to the corresponding relative mRNA levels of these genes in the control rats.

Findings of western blotting: Levels of total Raf-1, MEK1/ 2, ERK1/2, and p-BAD were not significantly different between control and VCR-treated group (Figs. 4,A-C). Kidney tissue obtained from VCR-treated rats showed significant increases in levels of p-Raf-1 (Ser338), p-MEK1/2 (Ser217/ 221), p-ERK1/2 (Thr202/Tyr204), with no alterations in levels of p-BAD (Ser112) (Figs. 4A-C, 5A). In addition, levels of Bcl-2 were significantly decreased (Fig. 5B) whereas levels of P53, Bax, cleaved caspase-3 were significantly increased in VCR-treated rats (Fig. 5C).

Histopathological alterations: The renal cortex of VCRtreated rats showed alterations in both renal tubules and glomeruli of VCR-treated rats (Fig. 6). Tubular alterations appeared in the form of severing degeneration, dilation, vacuolization, and necrosis in both proximal and distal convoluted tubules with an accumulation of hyaline casts in their lumen. Tubular cells showed karyolysis, and karyorrhexis and pyknosis. On the other hand, their glomeruli showed congestion with no hypercellularity but with thinning and detached of the basement membrane. 

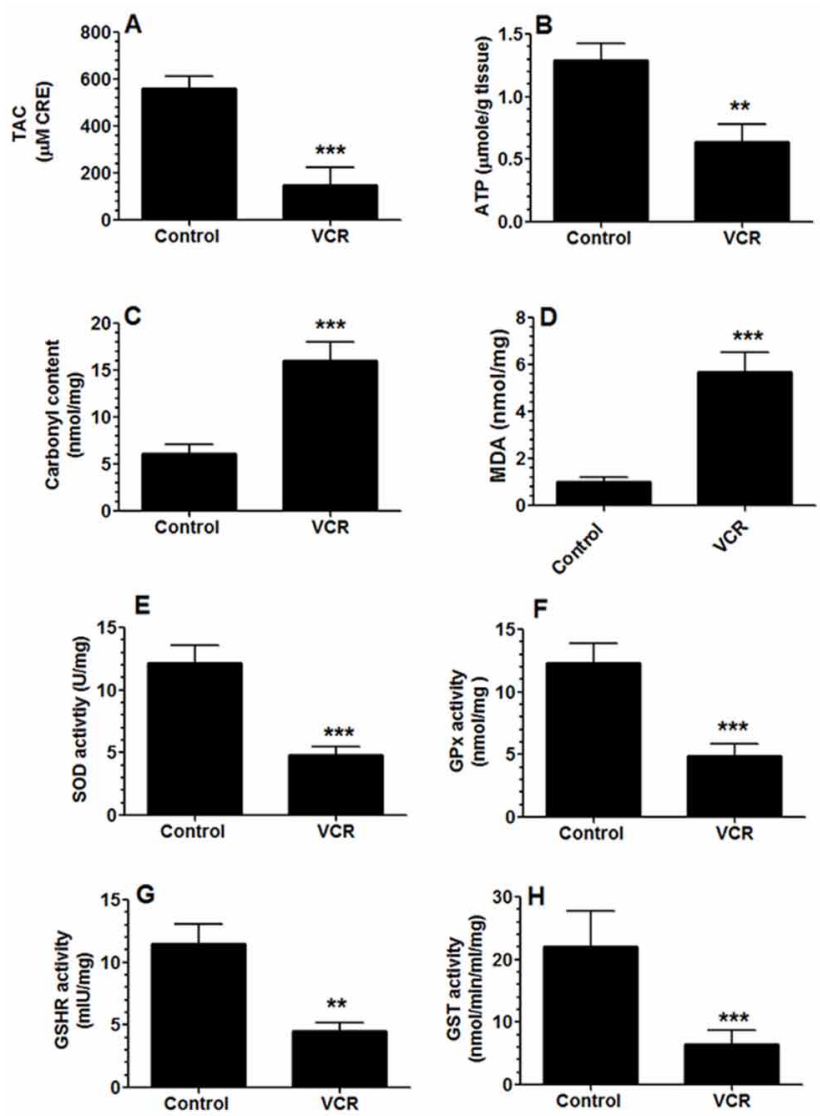

Fig. 2. Biochemical parameters in the renal homogenates of both control and vincristine (VCR)-treated rats. Values are expressed as Mean \pm SD 10 rats/group. Values were considered significantly different at $* \mathrm{P}<0.05$. VCR: Vincristine.
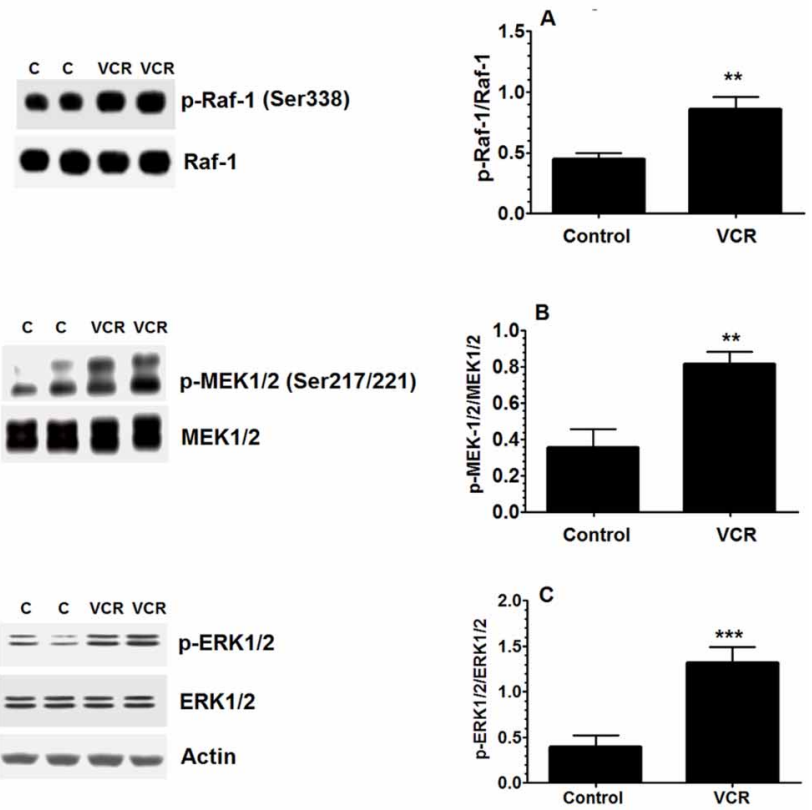
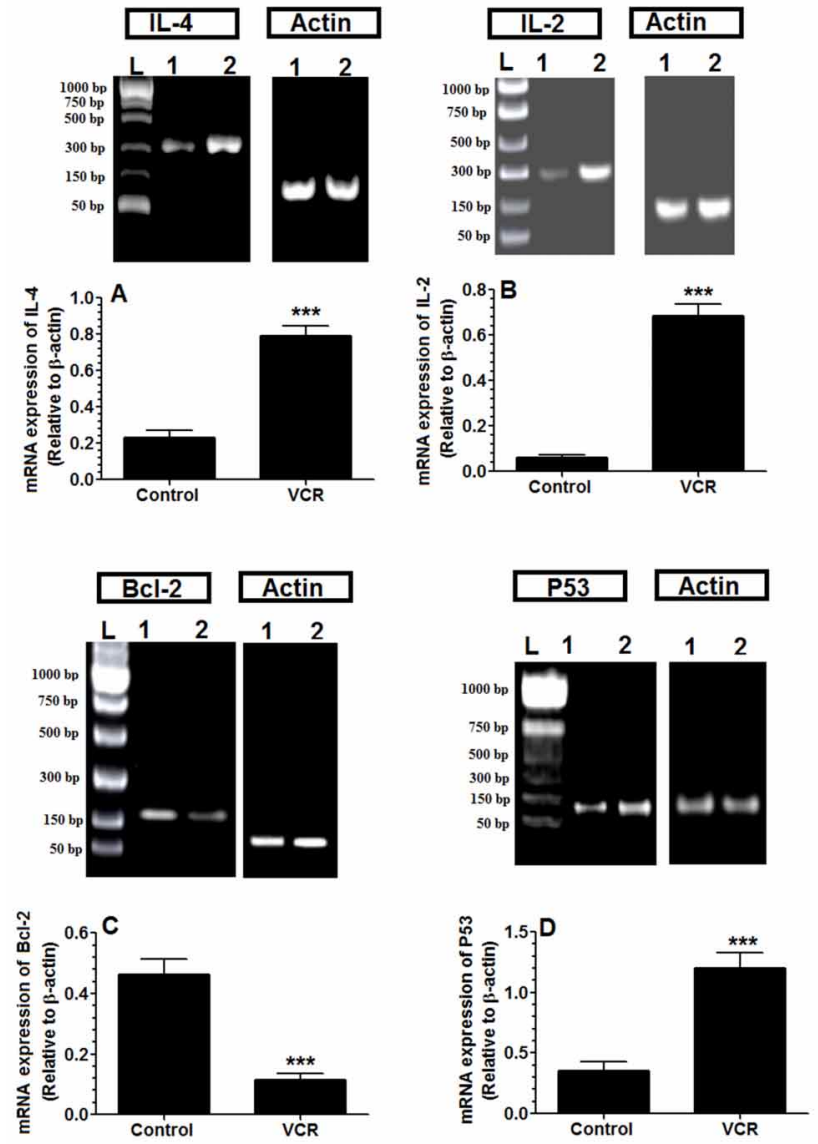

Fig. 3. Relative expression of mRNA levels of IL-4 (A), IL-12 (B) $\mathrm{Bcl}-2$ (C), P53 (D) in relation to the expression of the reference gene, $\beta$-actin in the kidneys of both control (lane 1) and vincristine (VCR, lane 2)-treated rats. Values are expressed as Mean \pm SD 6 rats/group. Values were considered significantly different at $* * \mathrm{P}$ $<0.01$ and $* * * \mathrm{P}<0.001$

Fig. 4. Protein levels of total Raf-1 (A), MEK1/2 (B) and ERK1/2 (C) as well as p-Raf-1 (Ser338), p-MEK1/2 ( Ser217/221) and pERK1/2 (Thr202/Tyr204) in the kidneys of both control (C) and vincristine (VCR)-treated rats. Values are expressed as Mean \pm SD for 6 rats in each group. Values are expressed as Mean \pm SD 6 rats/ group. Values were considered significantly different at $* * \mathrm{P}<0.01$ and $* * * \mathrm{P}<0.001$. 


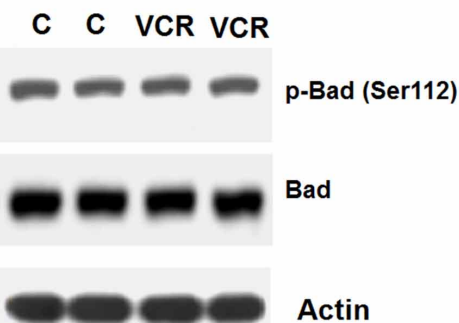

C C VCR VCR
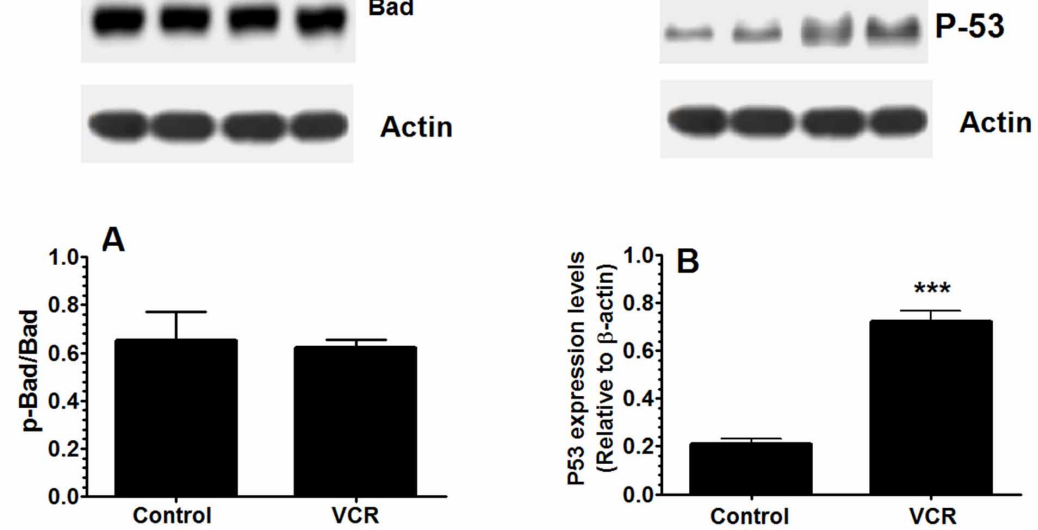

C C VCR VCR
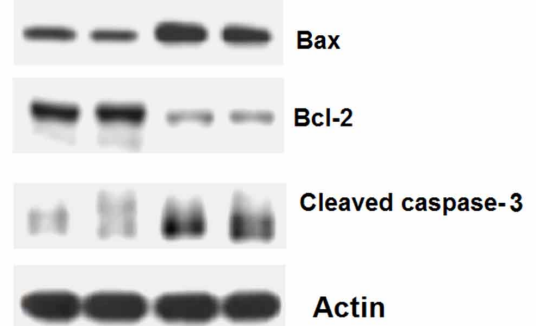

\section{C}

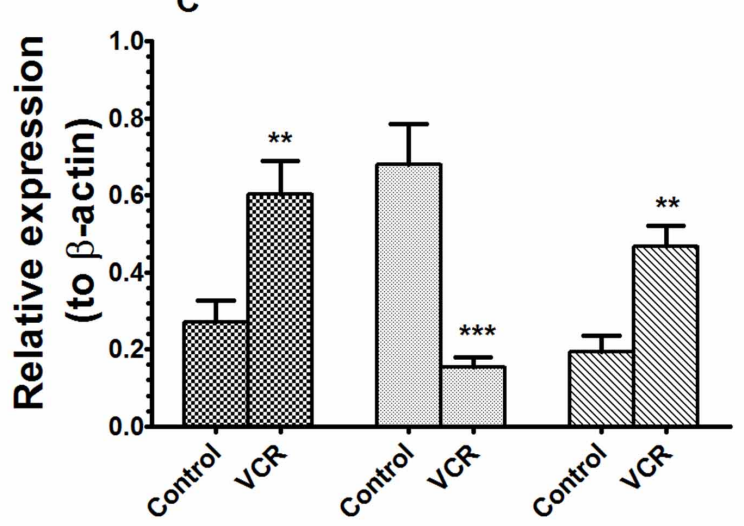

Fig. 5. Protein levels of total Bad and p-Bad (Ser112) (A) and P53 (B) as well as Bcl-2, Bax and cleaved caspase-3 (C) in the kidney tissues of both control (C) and vincristine (VCR)-treated rats. Values are expressed as for Mean \pm SD 6 rats/group. Values were considered significantly different at $* * \mathrm{P}<0.01$ and $* * * \mathrm{P}<0.001$

\section{DISCUSSION}

The incidence of drug-induced nephrotoxicity is continuously increasing (Singh et al., 2003) and nephrotoxicity due to adverse drug reaction of many anticancer drugs is well established (Suarez et al.; Glezerman et al.). Few studies have been carried out to investigate the adverse effect of long-term of VCR administration on kidney function in adult human or animals. In this context, the present study evaluates the kidney function and possible damage induced by i.p VCR sulfate administration for 30 days which confirms its nephrotoxicity as evident by altered kidney function and glomerular histopathological alterations, which are considered as major tests to evaluate kidney function in animals (Amin et al., 2004). Molecular mechanisms show that VCR induces renal cell death by enhancing oxidative stress and inflammation, which eventually lead to activate Raf-1/MEK1/ 2ERK1/2 induced apoptosis.

Indices of renal functional capacity include the analysis of the serum and urinary levels of major electrolytes, urea and $\mathrm{Cr}$. It is well documented that high serum urea and $\mathrm{Cr}$ levels are considered the major nephrotoxic markers (Adelman et al., 1981). Creatinine $(\mathrm{Cr})$ is a product of creatine metabolism in muscles and is freely filtered by the glomerulus without further significant metabolism or reabsorption (Stevens \& Levey, 2005). Hence, serum $\mathrm{Cr}$ levels do not increase significantly until kidney function is considerably compromised (Salgado et al., 2010). Glomerulus filtration rate (GFR) is the most widely accepted calculated parameter used for the qualitative and quantitative evaluation of the kidney excretory capacity (El-Minshawy et al., 2010). In clinical practice, GFR is most accurately obtained from $\mathrm{Cr}$ clearance (Ccr) based on a urine sample collected during $24 \mathrm{~h}$ (El-Minshawy et al.). The significant increase in blood $\mathrm{Cr}$ and urea has been described to be associated with distinct renal structural damage (Eslami et al., 2011) and a reciprocal relationship between serum $\mathrm{Cr}$ and $\mathrm{Ccr}$ has been described (Kassirer et al., 1971). In addition, the functional glomerulus restricts the penetration of high molecular weight proteins from blood to nephrons (Finn \& Porter, 2003). and early kidney 

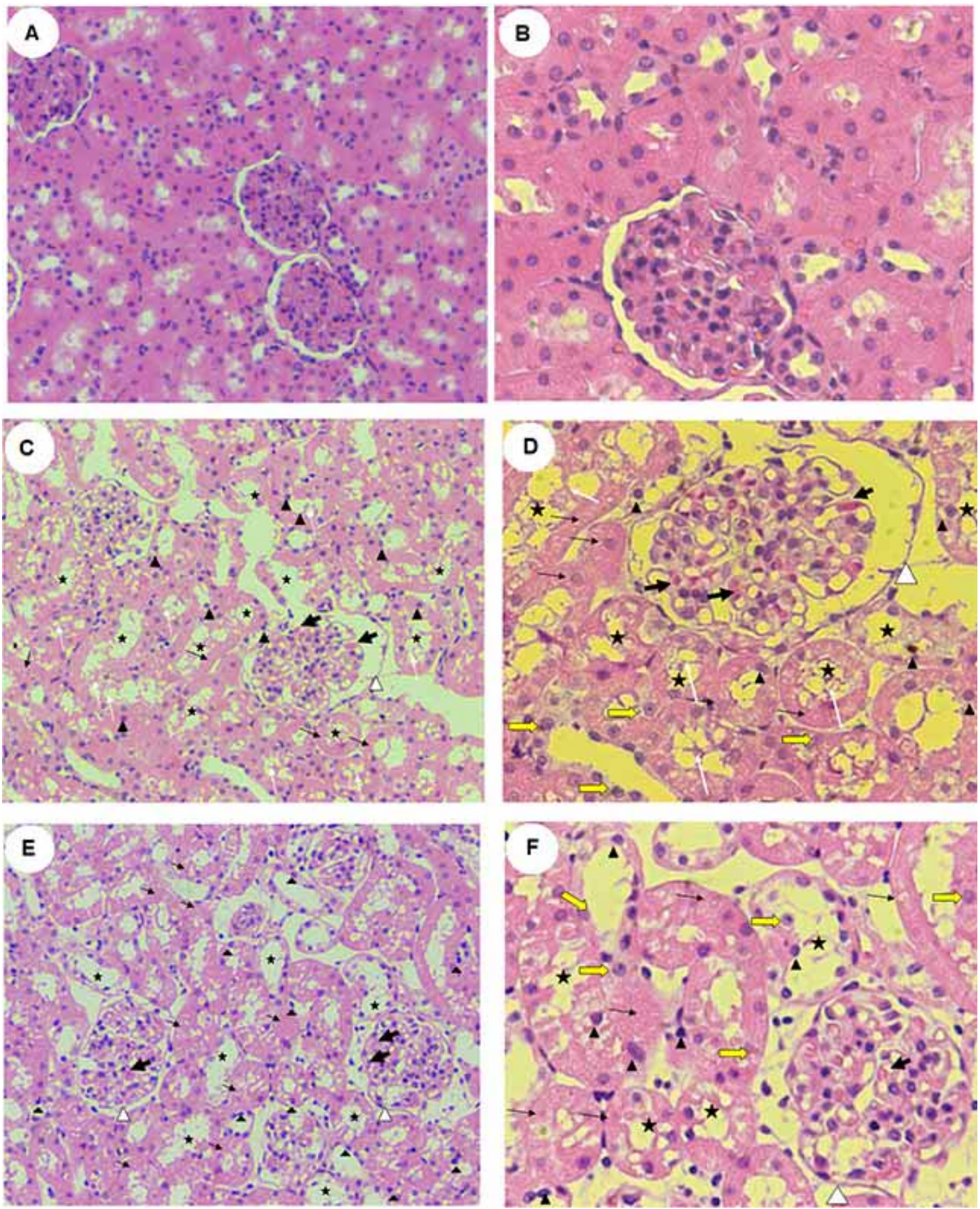

Fig. 6. Photomicrograph of renal cortex obtain from sample rats/groups. A and B were taken a control rat at magnifications of 200 and 400X, respectively these tissues showing normal renal cortex architectures including dense rounded renal corpuscles comprising the glomeruli surrounded by capsule glomeruli with small subcapsular spaces. Both proximal lined with brush border and normal distal convoluted tubules well preserved and both line with simple cuboidal epithelium. C-F: were taken from VCR treated rats where C and E were photographed at 200X whereas D and F were photographed at $400 \mathrm{X}$. The renal cortex of these rats showed tubular alterations in the form of severe degeneration, vacuolization, and necrosis (*) in both proximal and distal convoluted tubules. Dilation was dominant in both tubules and their cells showed karyolysis (black arrow), and karyorrhexis (yellow arrow) and pyknosis (black arrowhead). In addition, hyaline casts were seen abundant (white arrow). Glomeruli of these rats showed congestion (wide black arrow) with no hypercellularity but with thinning and detached of the basement membrane. 
injury and damage can be detected using measurements of protein in the urine (Guder \& Hofmann, 1992).

In support to the above-mentioned discussion, i.p VCR administration for 30 days resulted in severe renal injury, as evidenced by the significant increases in serum $\mathrm{Cr}$, urea and BUN levels and the parallel decreases in urine volume and $\mathrm{pH}$ as well as low urinary levels of levels of $\mathrm{Na}+\mathrm{Ccr}$, and urea and high urinary protein levels. Generally, Hydrogen ion $(\mathrm{H}+)$ secretion into urine takes place only in the distal tubules (Rodríguez Soriano, 2002). Hence, the enhanced urinary protein levels, impairment of reabsorption and urine acidification indicate disturbances in glomerulus function, proximal tubules dysfunction, and distal tubules, respectively. In support, histological data of VCR-treated rats revealed severe glomerular congestion and dilation, tubular vacuolization, degeneration and signs of necrosis throughout the cortex in renal tissues of rats. However, taking into account that there were no significant alterations in food or water intake during $24 \mathrm{~h}$ urine collection, we could conclude that it will be unlikely that the $\mathrm{pH}$ drop observed in the VCR-treated rats may result from alterations in water or food consumption.

On the other hand, ROS are major key players in druginduced renal toxicity (Kehrer 1993). GSH, SOD, and catalase (CAT) compose both enzymatic and nonenzymatic antioxidant defense system needed to detoxify reactive molecules and/or repair cell damage (Whidden et al., 2011). Concomitantly, other GSH-dependent enzymes are needed to maintain intracellular redox state including GPx, GST, and GR (Halliwell, 1996). In this study, activities of GPx, GST, GR, and SOD were significantly inhibited whereas levels of MDA were significantly increased in renal tissue of VCR-treated rats. This could be explained by the overconsumption of these enzymes and GSH in ROS detoxification generated by VCR. Indeed, independent of its antimitotic activity, vinca alkaloid including VCR induce mitochondrial transmembrane potential loss and interfere and inhibit electron transport chain (ETC), leading to generate high levels of ROS and activate apoptosis (Muthuraman \& Singh; Canta et al.; Vashistha et al.).

In this study, the serum levels of uric acid was analyzed as a marker of oxidative stress. Uric acid is the end product of purine catabolism and is a potent scavenger of peroxyl and hydroxyl radicals and of singlet oxygen generates by peroxynitrite (Ames et al., 1981; Glantzounis et al., 2005). Moreover, uric acid is a powerful inhibitor of free radicals generated by decomposition of peroxynitrite (Squadrito et al., 2000; Wang et al., 2015). The loss of urate oxidase resulted in increased plasma uric acid level and improved antioxidant defense (Glantzounis et al.). The reduction of serum uric acid level and consequently reduced urinary excretion of the compound in VCR-treated rats may reflect a compensation of an excessive oxidative stress, which is, as mentioned above, an essential, potential element of pathomechanism of the VCR-induced nephrotoxicity and its associated oliguria or kidney failure. Therefore, it can be concluded that the advanced oxidative stress in kidneys induced by VCR caused a secondary indirect "exhaustion" the compensatory antioxidant mechanisms, including reduction of plasma uric acid level. This has also been confirmed in animal studies and clinical observations. An indirect confirmation of the role of uric acid as an antioxidant in the course of kidney and bladder damage was also provided by clinical observations which showed evidence for a role of uric acid in the pathogenesis of kidney damage caused by VCR (Wang et al., 2015; Dobrek et al., 2017).

Nephrotoxic drugs may result in the glomerulus, tubules and interstitial inflammation (Muthuraman \& Singh; Canta et al.; Vashistha et al.). Generally, glomerulonephritis is associated with proteinuria whereas interstitial nephritis is associated with oliguria (Cruz \& Perazella, 1998), as found in the VCR-treated rate in the current study. In order to observe the pro-inflammatory role of VCR in the kidneys of rats, mRNA levels of both IL-4 and IL-12 in were measured in the rat's kidneys and an enhanced mRNA level of both genes was observed. IL-4 is secreted from Th2 lymphocytes with multiple functions such as inducing differentiation of Th0 to Th2 and suppressing the inflammatory mediator's secretions from macrophages and monocytes including IL6, IL-8, and tumor necrosis factor-alpha (TNF-a) (Lakkis et al., 1996). On the other hand, IL-12 is an inflammatory cytokine secreted from neutrophils, dendritic cells, and macrophages that stimulates the differentiation of naive $\mathrm{T}$ cells into Th1 cells to induce production of interferongamma (IFN-g) and TNF-a (Lakkis et al.). In this study, it can be suggested that the increased level of IL-4 could be a negative feedback mechanism to inhibit Th1 cells to reduce inflammation.

Oxidative stress is a well known potent inducer of ERK1/2 activation in various tissues including the renal tissue (Pat et al., 2005; Kwon et al., 2006; Qin et al., 2015). Associated with the enhanced oxidative stress response, to best of our knowledge, this study is the first to demonstrate that the protein levels of p-ERK1/2 and their up-stream regulatory enzymes, p-Raf-1 and p-MEK1/2 were significantly increased in renal tissues of rats repeatedly treated with VCR. Interestingly, protein levels of p-p90RSK and p-Bad (Ser112) were significantly decreased whereas mRNA and protein levels of P53 were significantly increased, suggesting an active ERK1/2-P53 apoptotic pathway. Indeed, as a survivor factor, MEK1/2-ERK1/2 
pathway prevents apoptotic cell death via phosphorylation inactivation of the pro-apoptotic protein, Bad at Ser residue through phosphorylation of p90RSK to inhibit the release of the pro-apoptotic protein Bax and activation of caspases3 (Zha et al., 1996; Lu \& Xu; Koh, 2008). As a pro-apoptotic factor, ERK1/2 induces and enhances mRNA levels of both Bax and P53 and their transcriptional activities (Cagnol \& Chambard, 2010). These results could explain the significant decreases in Bcl-2 mRNA and protein levels and the significant increases in protein levels of Bax and cleaved caspase-3. Indeed, P53 can induce intrinsic apoptosis either by enhancing the expression of the proapoptotic protein, Bax or by downregulating the expression of the antiapoptotic protein, Bcl-2 (Elmore et al., 2007).

However, one limitation of this study is that it investigated the effect of i.p. administration of VCR sulfate on rats' kidney function which is not clinically relevant to VCR rout of administration in human (i.v.). However, this procedure has been confirmed to investigate the efficiency, safety and bioavailability of VCR in laboratory animals including rats and cats with promising findings have been reported and trails are now being translated into human (Bairy et al., 2003; Park et al., 2012; Voorhorst et al., 2014). This is important given the adverse side effects associated with the i.v. route of VCR administration including sudden extravasations which can causes severe tissue necrosis of patient limbs (Voorhorst et al.). In addition, these studies have also shown that i.p. administration of VCR is safe and effective alternative for the i.v. administration rout of VCR in chemotherapeutics. Interestingly, i.p chemotherapy has been reported for the treatment of cancer in the peritoneal cavity of human (Markman et al., 2003). In addition, i.p. administration of carboplatin, a related anticancer drug has been described as an effective method for systemic chemotherapy in humans (Miyagi et al., 2005). Hence, the finding of this study could be important and contradict these studies about the safety of i.p. administration of VCR in laboratory animals after prolonged repetitive administration. Supporting to these findings, a recent study showed severe hepatocytes damage and altered liver pathology in VCR treated rats (Shati \& Elsaid, 2018). These finding could explain the enhanced death rate seen in VCR treated rats of this study. Another limitation to this study is that the effect of VCR on hematological parameters was not measured even it could add more information on the toxicological profile of VCR administration using i.p route of administration.

In conclusion, findings of the current study demonstrate that sub-chronic administration of VCR by i.p. the route is nephrotoxic in rats. Such nephrotoxicity was mediated at least by induction of oxidative stress, provoking of inflammation and activation of mitochondrial cell pathway of apoptosis.

\section{ACKNOWLEDGMENTS}

The author would like to thank the animal facility staff at King Khalid University for their help and support of the current study and would like to thanks the technical staff at the College of Science at KKU for measuring some of the biochemical parameters.

SHATI, A. A. La administración subcrónica de sulfato de vincristina induce daño renal y apoptosis en ratas por inducción de estrés oxidativo y activación de la transducción de señales Raf1MEK1/2-Erk1/2. Int. J. Morphol., 37(1):273-283, 2019.

RESUMEN: A pesar de ser uno de los medicamentos de mayor eficacia contra el cáncer, aún no se ha establecido la nefrotoxicidad de la vincristina (VCR) en animales y humanos. Por lo tanto, este estudio evalúa el efecto nefrotóxico de la VCR en ratas después de la administración subcrónica a largo plazo. Las ratas se dividieron en 2 grupos $(\mathrm{n}=10 /$ grupo) de control y ratas tratadas con VCR $(50 \mathrm{mg} / \mathrm{kg})$. Los tratamientos se llevaron a cabo durante 30 días consecutivos, después de los cuales se evaluaron una serie de experimentos bioquímicos y moleculares relacionados con la función renal. La administración de VCR disminuyó significativamente la tasa de supervivencia $(69,8 \%)$, dificultó la función renal, lo que se observó además en los bajos niveles de creatinina $(\mathrm{Cr})(\mathrm{Ccr})$, los niveles séricos elevados de urea y $\mathrm{Cr}$, un nivel más alto de proteína urinaria, los que dieron lugar a alteraciones patológicas severas de la corteza, incluido el glomérulo congestión y daño, como también degeneraciones vasculares, incluyendo la necrosis de los túbulos contorneados proximales y distales. Mecánicamente, el VCR redujo el potencial antioxidante renal y los niveles de ATP, mejoró la peroxidación lipídica y la inflamación inducida. Además, la VCR indujo la activación de la vía de señalización Raf-1-MEK1 / 2-ERK1 / 2 que conduce a la regulación negativa de Bcl-2 y la regulación positiva de P53, Bax y la caspasa-3. En conclusión, estos hallazgos muestran un efecto nefrotóxico del sulfato de VCR en ratas después de la administración subcrónica. Dicho efecto fue mediado por la activación de la apoptosis inducida por ERK1 / 2.

PALABRAS CLAVE: Vincristina; Nefrotoxicidad; Estrés oxidativo; Apoptosis; Ratas.

\section{REFERENCES}

Adelman, R. D.; Spangler, W. L.; Beasom, F.; Ishizaki, G. \& Conzelman, G. Frusemide enhancement of netilmicin nephrotoxicity in dogs. $J$. Antimicrob. Chemother., 7(4):431-40, 1981.

Ames, B. N.; Cathcart, R.; Schwiers, E. \& Hochstein, P. Uric acid provides an antioxidant defense in humans against oxidant- and radical-caused aging and cancer: a hypothesis. Proc. Natl. Acad. Sci. U. S. A., 78(11):6858-62, 1981.

Amin, R. P.; Vickers, A. E.; Sistare, F.; Thompson, K. L.; Roman, R. J.; Lawton, M.; Kramer, J.; Hamadeh, H. K.; Collins, J.; Grissom, S.; 
Bennett, L.; Tucker, C. J.; Wild, S.; Kind, C.; Oreffo, V.; Davis, J. W. 2nd; Curtiss, S.; Naciff, J. M.; Cunningham, M.; Tennant, R.; Stevens, J.; Car, B.; Bertram, T. A. \& Afshari, C. A. Identification of putative gene based markers of renal toxicity. Environ. Health Perspect., 112(4):465-79, 2004.

Arany, I.; Megyesi, J. K.; Kaneto, H.; Price, P. M. \& Safirstein, R. L. Cisplatin-induced cell death is EGFR/src/ERK signaling dependent in mouse proximal tubule cells. Am. J. Physiol. Renal Physiol., 287(3):F543-9, 2004.

Arnon, J.; Meirow, D.; Lewis-Roness, H. \& Ornoy, A. Genetic and teratogenic effects of cancer treatments on gametes and embryos. Hum. Reprod. Update, 7(4):394-403, 2001.

Bedikian, A. Y.; Vardeleon, A.; Smith, T.; Campbell, S. \& Namdari, R. Pharmacokinetics and urinary excretion of vincristine sulfate liposomes injection in metastatic melanoma patients. J. Clin. Pharmacol., 46(7):727-37, 2006.

Bellone, J. D. Treatment of vincristine extravasation. JAMA, 245(4):343, 1981.

Billecke, C.; Finniss, S.; Tahash, L.; Miller, C.; Mikkelsen, T.; Farrell, N. P. \& Bögler, O. Polynuclear platinum anticancer drugs are more potent than cisplatin and induce cell cycle arrest in glioma. Neuro Oncol., 8(3):215-26, 2006.

Blasko, G. \& Cordel, G. A. Chapter 1. Isolation, Structure Elucidation, and Biosynthesis of the Bisindole Alkaloids of Catharanthus. In: Brossi, A. \& Suffness, M. (Eds.). Antitumor Bisindole Alkaloids from Catharanhus roseus (L). Vol. 37. The Alkaloids: Chemistry and Pharmacology. San Diego, Academic Press, 1990. pp.1-76.

Cagnol, S. \& Chambard, J. C. ERK and cell death: mechanisms of ERKinduced cell death--apoptosis, autophagy and senescence. FEBS J., 277(1):2-21, 2010.

Canta, A.; Pozzi, E. \& Carozzi, V. A. Mitochondrial Dysfunction in Chemotherapy-Induced Peripheral Neuropathy (CIPN). Toxics, 3(2):198-223, 2015.

Cassidy, H.; Radford, R.; Slyne, J.; O'Connell, S.; Slattery, C.; Ryan, M. P. \& McMorrow, T. The role of MAPK in drug-induced kidney injury. $J$. Signal Transduct., 2012:463617, 2012.

Cave, T. A.; Norman, P. \& Mellor, D. Cytotoxic drug use in treatment of dogs and cats with cancer by UK veterinary practices (2003 to 2004). J. Small Anim. Pract., 48(7):371-7, 2007.

Cheung, E. C. \& Slack, R. S. Emerging role for ERK as a key regulator of neuronal apoptosis. Sci. STKE, 2004(251):PE45, 2004.

Choy, D. S. Effective treatment of inadvertent intramuscular administration of vincristine. JAMA, 241(7):695, 1979.

Cruz, D. N. \& Perazella, M. A. Drug-induced acute tubulointerstitial nephritis: the clinical spectrum. Hosp. Pract. (1995), 33(2):151-2, 1998.

da Silva, C. P.; de Oliveira, C. R.; da Conceição, M. \& de Lima, P. Apoptosis as a mechanism of cell death induced by different chemotherapeutic drugs in human leukemic T-lymphocytes. Biochem. Pharmacol., 51(10):1331-40, 1996.

Dennison, J. B.; Jones, D. R.; Renbarger, J. L. \& Hall, S. D. Effect of CYP3A5 expression on vincristine metabolism with human liver microsomes. J. Pharmacol. Exp. Ther., 321(2):553-63, 2007.

Dobrek; Skowron, B.; Baranowska, A.; Poszaj, K.; Badziul, D. \& Thor, P. The influence of oxazaphosphorine agents on kidney function in rats. Medicina (Kaunas), 53(3):179-89, 2017.

Egbelakin, A.; Ferguson, M. J.; MacGill, E. A.; Lehmann, A. S.; Topletz, A. R.; Quinney, S. K.; Li, L.; McCammack, K. C.; Hall, S. D. \& Renbarger, J. L. Increased risk of vincristine neurotoxicity associated with low CYP3A5 expression genotype in children with acute lymphoblastic leukemia. Pediatr. Blood Cancer, 56(3):361-7, 2011.

El-Minshawy, O.; Saber, R. A. \& Osman, A. 24-hour creatinine clearance reliability for estimation of glomerular filtration rate in different stages of chronic kidney disease. Saudi J. Kidney Dis. Transpl., 21(4):68693, 2010.

Elmore, S. Apoptosis: a review of programmed cell death. Toxicol. Pathol., 35(4):495-516, 2007.
Eslami, S. H.; Ebrahimzadeh, M. A.; Moghaddam, A. H.; Nabavi, S. F.; Jafari, N. \& Nabavi, S. M. Renoprotective effect of Eryngium caucasicum in gentamicin-induced nephrotoxic mice. Arch. Biol. Sci., 63:157-60, 2011.

Finn, W. F. \& Porter, G. A. Urinary Biomarkers and Nephrotoxicity. In: de Broe, M. E.; Porter, G. A.; Bennett, W. M. \& Verpooten, G. A. (Eds.). Clinical Nephrotoxins. Springer, Dordrecht, 2003. pp.621-55.

Glantzounis, G. K.; Tsimoyiannis, E. C.; Kappas, A. M. \& Galaris, D. A. Uric acid and oxidative stress. Curr. Pharm. Des., 11(32):4145-51, 2005.

Glezerman, I.; Kris, M. G.; Miller, V.; Seshan, S. \& Flombaum, C. D. Gemcitabine nephrotoxicity and hemolytic uremic syndrome: report of 29 cases from a single institution. Clin. Nephrol., 71(2):130-9, 2009.

Guder, W. G. \& Hofmann, W. Markers for the diagnosis and monitoring of renal tubular lesions. Clin. Nephrol., 38 Suppl. 1:S3-7, 1992.

Halliwell, B. Antioxidants in human health and disease. Ann. Rev. Nutr., 16:3350, 1996.

Jordan, M. A. Mechanism of action of antitumor drugs that interact with microtubules and tubulin. Curr. Med. Chem. Anticancer Agents, 2(1):117, 2002.

Kassirer, J. P. Clinical evaluation of kidney function--glomerular function. N. Eng. J. Med., 285(7):385-9, 1971.

Kaur, G.; Jaggi, A. S. \& Singh, N. Exploring the potential effect of Ocimum sanctum in vincristine-induced neuropathic pain in rats. J. Brachial Plex. Peripher. Nerve Inj., 5:3, 2010.

Kehrer, J. P. Free radicals as mediators of tissue injury and disease. Crit. Rev. Toxicol., 23(1):21-48, 1993.

Kesik, V.; Kurt, B.; Tunc, T.; Karslioglu, Y.; Citak, E. C.; Kismet, E. \& Koseoglu, V. Adrenomedullin worsens skin necrosis in rats subjected to vincristine-induced extravasation. Clin. Exp. Dermatol., 35(8):897-901, 2010.

Khalil, H. A.; Belal, T. S.; El-Yazbi, A. F. \& Hamdy, D. A. The effect of increased lipoproteins levels on the disposition of vincristine in rat. Lipids Health Dis., 15:152, 2016.

Koh, P. O. Melatonin attenuates the focal cerebral ischemic injury by inhibiting the dissociation of pBad from 14-3-3. J. Pineal Res., 44(1):101-6, 2008.

Kohda, Y.; Hiramatsu, J. \& Gemba, M. Involvement of MEK/ERK pathway in cephaloridine-induced injury in rat renal cortical slices. Toxicol. Lett., 143(2):185-94, 2003.

Kulich, S. M. \& Chu, C. T. Sustained extracellular signal-regulated kinase activation by 6-hydroxydopamine: implications for Parkinson's disease. J. Neurochem., 77(4):1058-66, 2001.

Kumar, A. Vincristine and vinblastine: a review. Int. J. Med. Pharm. Sci., 6(1):23-30, 2016

Lakkis, F. G.; Baddoura, F. K.; Cruet, E. N.; Parekh, K. R.; Fukunaga, M. \& Munger, K. A. Anti-inflammatory lymphokine mRNA expression in antibody-induced glomerulonephritis. Kidney Int., 49(1):117-26, 1996.

Lameire, N.; Van Biesen, W. \& Vanholder, R. Electrolyte disturbances and acute kidney injury in patients with cancer. Semin. Nephrol., 30(6):53447, 2010.

$\mathrm{Lu}, \mathrm{Z} . \& \mathrm{Xu}, \mathrm{S}$. ERK1/2 MAP kinases in cell survival and apoptosis. IUBMB Life, 58(11):621-31, 2006.

Markman, M. Intraperitoneal antineoplastic drug delivery: rationale and results. Lancet Oncol., 4(5):277-83, 2003.

Martins, D. B.; Lopes, S. T. A.; Mazzanti, C. M.; Spanevello, R.; Schmatz, R.; Corrêa, M.; Stefanello, N.; Schetinger, M. R.; Morsch, V. \& Veiga, A. P. M. Lipid peroxidation in rats treated with vincristine sulphate and nandrolone decanoate. Arq. Bras. Med. Vet. Zootec., 63(1):107-13, 2011.

Miyagi, Y.; Fujiwara, K.; Kigawa, J.; Itamochi, H.; Nagao, S.; Aotani, E.; Terakawa, N.; Kohno, I. \& Sankai Gynecology Study Group (SGSG). Intraperitoneal carboplatin infusion may be a pharmacologically more reasonable route than intravenous administration as a systemic chemotherapy. A comparative pharmacokinetic analysis of platinum using a new mathematical model after intraperitoneal vs. intravenous infusion of carboplatin--a Sankai Gynecology Study Group (SGSG) study. Gynecol. Oncol., 99(3):591-6, 2005. 
Mollinedo, F. \& Gajate, C. Microtubules, microtubule-interfering agents and apoptosis. Apoptosis, 8(5):413-50, 2003.

Muthuraman, A. \& Singh, N. Attenuating effect of hydroalcoholic extract of Acorus calamus in vincristine-induced painful neuropathy in rats. $J$. Nat. Med., 65(3-4):480-7, 2011.

Nowak, G. Protein kinase C-alpha and ERK1/2 mediate mitochondrial dysfunction, decreases in active $\mathrm{Na}+$ transport, and cisplatin-induced apoptosis in renal cells. J. Biol. Chem., 277(45):43377-88, 2002.

Park, H. J.; Kim, Y. H.; Koh, H. J.; Park, C. S.; Kang, S. H.; Choi, J. H. \& Moon, D. E. Analgesic effects of dexmedetomidine in vincristineevoked painful neuropathic rats. J. Korean Med. Sci., 27(11):1411-7, 2012.

Pat, B.; Yang, T.; Kong, C.; Watters, D.; Johnson, D. W. \& Gobe, G. Activation of ERK in renal fibrosis after unilateral ureteral obstruction: modulation by antioxidants. Kidney Int., 67(3):931-43, 2005.

Potocnjak, I. \& Domitrovic, R. Carvacrol attenuates acute kidney injury induced by cisplatin through suppression of ERK and PI3K/Akt activation. Food Chem. Toxicol., 98(Pt. B):251-61, 2016.

Qin, J.; Mei, W. J.; Xie, Y. Y.; Huang, L.; Yuan, Q. J.; Hu, G. Y.; Tao, L. J. \& Peng, Z. Z. Fluorofenidone attenuates oxidative stress and renal fibrosis in obstructive nephropathy via blocking NOX2 (gp91phox) expression and inhibiting ERK/MAPK signaling pathway. Kidney Blood Press Res., 40(1):89-99, 2015.

Rodríguez Soriano, J. Renal tubular acidosis: the clinical entity. J. Am. Soc. Nephrol., 13(8):2160-70, 2002.

Rose, B. A.; Force, T. \& Wang, Y. Mitogen-activated protein kinase signaling in the heart: angels versus demons in a heart-breaking tale. Physiol. Rev., 90(4):1507-46, 2010.

Said, R. \& Tsimberidou, A. M. Pharmacokinetic evaluation of vincristine for the treatment of lymphoid malignancies. Expert Opin. Drug Metab. Toxicol., 10(3):483-94, 2014.

Salahudeen, A. K. \& Bonventre, J. V. Onconephrology: the latest frontier in the war against kidney disease. J. Am. Soc. Nephrol., 24(1):26-30, 2013.

Salgado, J. V.; Neves, F. A.; Bastos, M. G.; França, A. K.; Brito, D. J.; Santos, E. M. \& Salgado Filho, N. Monitoring renal function: measured and estimated glomerular filtration rates - a review. Braz. J. Med. Biol. Res., 43(6):528-36, 2010.

Shati, A. A. \& Elsaid, F. G. Hepatotoxic effect of subacute vincristine administration activates necrosis and intrinsic apoptosis in rats: protective roles of broccoli and Indian mustard. Arch. Physiol. Biochem., $1: 1-11,2018$.

Singh, N. P.; Ganguli, A. \& Prakash, A. Drug-induced kidney diseases. J. Assoc. Physicians India, 51:970-9, 2003.

Squadrito, G. L.; Cueto, R.; Splenser, A. E.; Valavanidis, A.; Zhang, H.; Uppu, R. M. \& Pryor, W. A. Reaction of uric acid with peroxynitrite and implications for the mechanism of neuroprotection by uric acid. Arch. Biochem. Biophys., 376(2):333-7, 2000.

Stanciu, M.; Wang, Y.; Kentor, R.; Burke, N.; Watkins, S.; Kress, G.; Reynolds, I.; Klann, E.; Angiolieri, M. R.; Johnson, J. W. \& DeFranco, D. B. Persistent activation of ERK contributes to glutamate-induced oxidative toxicity in a neuronal cell line and primary cortical neuron cultures. J. Biol. Chem., 275(16):12200-6, 2000.

Stevens, L. A. \& Levey, A. S. Measurement of kidney function. Med. Clin. North Am., 89(3):457-73, 2005.

Suarez, A.; McDowell, H.; Niaudet, P.; Comoy, E. \& Flamant, F. Longterm follow-up of ifosfamide renal toxicity in children treated for malignant mesenchymal tumors: an International Society of Pediatric Oncology report. J. Clin. Oncol., 9(12):2177-82, 1991.

Tang, D.; Wu, D.; Hirao, A.; Lahti, J. M.; Liu, L.; Mazza, B.; Kidd, V. J.; Mak, T. W. \& Ingram, A. J. ERK activation mediates cell cycle arrest and apoptosis after DNA damage independently of p53. J. Biol. Chem., 277(15):12710-7, 2002.

Upmanyu, R.; Saxena, Y. \& Dvivedi, J. Effects of vincristine on the bile flow in male albino rats. Indian J. Physiol. Pharmacol., 55(2):101-9, 2011.
Vashistha, B.; Sharma, A. \& Jain, V. Ameliorative potential of ferulic acid in vincristine-induced painful neuropathy in rats: An evidence of behavioral and biochemical examination. Nutr. Neurosci., 20(1):6070, 2017.

Voorhorst, M. J.; van Maarseveen, E. M.; van Lankveld, A. J. \& Teske, E. Bioavailability of cyclophosphamide and vincristine after intraperitoneal administration in cats. Anticancer Drugs, 25(10):12114, 2014.

Wang, C. C.; Weng, T. I.; Lu, M. Y.; Yang, R. S.; Lin, K. H.; Wu, M. H. \& Liu, S. H. Hemorrhagic cystitis in children treated with alkylating agent cyclophosphamide: The experience of a medical center in Taiwan. $J$. Formos. Med. Assoc., 114(8):691-7, 2015.

Wang, X.; Martindale, J. L. \& Holbrook, N. J. Requirement for ERK activation in cisplatin-induced apoptosis. J. Biol. Chem., 275(50):3943543, 2000.

Whidden, M. A.; Kirichenko, N.; Halici, Z.; Erdos, T. C. \& Tümer, N. Lifelong caloric restriction prevents age-induced oxidative stress in the sympathoadrenal system of Fischer $344 \mathrm{x}$ Brown Norway rats. Biochem. Biophys. Res. Commun., 408(3):454-8, 2011.

Yao, X.; Panichpisal, K.; Kurtzman, N. \& Nugent, K. Cisplatin nephrotoxicity: a review. Am. J. Med. Sci., 334(2):115-24, 2007.

Zha, J.; Harada, H.; Yang, E.; Jockel, J. \& Korsmeyer, S. J. Serine phosphorylation of death agonist BAD in response to survival factor results in binding to 14-3-3 not BCL-X(L). Cell, 87(4):619-28, 1996.

\section{Corresponding author: \\ Ali A. Shati \\ Biology Department \\ College of Science \\ King Khalid University \\ Abha \\ SAUDI ARABIA}

E-mail: aaalshati@kku.edu.sa

Received: 24-07-2018

Accepted: $29-10-2019$ 